\title{
Factors that interfere with oocyte quality for in vitro production of cattle embryos: effects of different developmental $\&$ reproductive stages
}

\author{
P.S. Baruselli ${ }^{1,5}$, E.O.S. Batista ${ }^{1}$, L.M. Vieira ${ }^{1}$, R.M. Ferreira ${ }^{1}$, B.G. Guerreiro ${ }^{1}$, B.M. Bayeux ${ }^{1}$, J.N.S. Sales ${ }^{2}$, \\ A.H. Souza ${ }^{3}$, L.U. Gimenes ${ }^{4}$ \\ ${ }^{1}$ Department of Animal Reproduction, USP, São Paulo, SP, Brazil. \\ ${ }^{2}$ Department of Veterinary Medicine, Universidade Federal de Lavras, Lavras, MG, Brazil. \\ ${ }^{3}$ Ceva Animal Health, Paulínia, SP, Brazil. \\ ${ }^{4}$ Department of Preventive Veterinary Medicine and Animal Reproduction, FCAV-UNESP, Jaboticabal, Brazil.
}

\begin{abstract}
The success of IVP is ultimately dependent on the number and quality of the cumulus-oocyte complexes (COC) harvested during the OPU procedure. Several factors appear to be critical to oocyte quality including follicle size, environment factors such as heatstress, genetic background, age and lactation status of donor animals, all having a remarkable influence on the results of IVP. The aim of this review is to highlight some critical areas that can help veterinary practitioners to enhance OPU efficiency and successfully implement IVP into their routine practice. Focus will be given to recent findings in the literature and underlying physiological aspects that may be interfering with the quality of oocytes addressed to IVP in cattle at younger ages (calves and prepubertal heifers), pregnant vs nonpregnant status, and possible interactions with lactation and days postpartum during OPU.
\end{abstract}

Keywords: bovine, embryo, IVF, oocyte, pregnancy.

\section{Introduction}

Oocyte collection by ovum pick-up (OPU) associated with in vitro production of embryos (IVP) are important technologies that can improve efficiency of both dairy and beef herds (Merton et al., 2003; Pontes et $a l ., 2010)$. The IVP industry is evolving fast in the last decade, and some parallel technologies such as genomics and the discovery of embryo production markers (i.e. AMH assay) are driving a more targeted and efficient genetic progress through IVP. For example, the use of genomic technology allows the identification of genetic superior animals at much earlier ages. As a result, producers are pushing both the industry and the scientific community to develop techniques that are more suited to younger animals sent to OPU-IVP routines, accelerating the genetic gain by decreasing generation intervals.

Despite of animal age in which OPU is performed, the overall success of IVP is ultimately dependent on the number and quality of the cumulusoocyte complexes (COC) harvested during the OPU procedure. Evidently, several factors appear to be critical to oocyte quality including follicle size (Lonergan et al., 1994; Seneda et al., 2001), environment factors such as heat-stress (Torres-Júnior $e t$ al., 2008; Ferreira et al., 2011; Ferreira et al., 2016), genetic background (Gimenes et al., 2015; Sales et al.,
2015), age (Batista et al., 2016a) and lactation status of donor animals (Baruselli et al., 2016), all having a remarkable influence on the results of IVP. Additionally, there is a growing body of scientific literature demonstrating the direct role of hormonal milieu during follicle development on oocyte quality. Focus has been given to the possible positive effects of circulating levels of $\mathrm{P} 4$ in determining oocyte quality in IVP (Lonergan, 2011). However, a recent study from our research group has demonstrated that neither exposure to lower levels of LH, nor cycles of P4, are limiting to oocyte viability and development to blastocyst stage (Batista et al., 2016b). Further research is needed to elucidate some of these rather complex interactions between reproductive hormones and oocyte quality.

Cattle breed is also one of the key factors that influence the efficiency of OPU-IVP. Interestingly, Bos indicus (also known as zebu breeds) and Bos taurus donors seem to have significant differences regarding the results of IVP (Pontes et al., 2010; Guerreiro et al., 2014a; Gimenes et al., 2015). It appears quite noticeable in most of the published literature that Bos indicus females have much greater numbers of oocytes retrieved during OPU; presumably due to greater numbers of ovarian follicle population and plasma anti-Müllerian concentration (Batista et al., 2014). Furthermore, zebu donors also have been shown to yield greater amounts of viable oocytes compared to Bos taurus donors (Guerreiro et al., 2014a; Gimenes et al., 2015).

Some management issues such as the type of diet and level of feed intake, as well as heat stress are widely known to have a great impact on oocyte quality and IVP. However, the interaction of these key factors may differ in Bos taurus and Bos indicus cattle. The level of energy intake for example, can affect circulating levels of insulin and IGF-1 (reviewed by Sartori et al., 2016). As a result, excessive increase in insulin concentration in blood, mainly in dairy cows later in lactation, are negatively associated with oocyte quality (reviewed by Baruselli et al., 2016). Exposure to heat stress is widely known to be deleterious to oocyte competence in Bos taurus cattle (Ferreira et al., 2011; Ferreira et al., 2016). Surprisingly, Bos indicus donors although more resistant to environmental heat stress conditions, are also affected by heat stress and may require nearly four months to recover oocyte quality to pre-heat stress levels, even after a short period of heat exposure (Torres-Júnior et al., 2008).

Altogether, several factors can be detrimental to 
oocyte quality and must be taken into account during IVP in cattle. Thus, the aim of this review is to highlight some critical areas that can help veterinary practitioners to enhance OPU efficiency and successfully implement IVP into their routine practice. Focus will be given to recent findings in the literature and underlying physiological aspects that may be interfering with the quality of oocytes addressed to IVP in cattle at younger ages (calves and prepubertal heifers), pregnant vs nonpregnant status, and possible interactions with lactation and days postpartum during OPU.

\section{Effect of different developmental \& reproductive stages on oocyte quality and in vitro embryo production}

\section{Oocyte quality and IVP in donor calves}

In cattle the population of ovarian follicles at birth is estimated at 235,000 (Ericksson, 1966; Betteridge et al., 1989). However, as in all mammals, this follicle population quickly decreases with aging (Ericksson, 1966). Therefore, young heifers have more antral follicles in their ovaries (Desjardins and Hafs, 1969), which could be associated with more efficient IVP. Previous studies have shown that calves require gonadotropin stimulation before oocyte collection and IVP to achieve acceptable results (Presicce et al., 1997; Maclellan et al., 1998; Taneja et al., 2000). Among the hormonal protocols employed in calves selected for oocyte recovery, most use follicle-stimulating hormone (FSH) treatment before using laparoscopic OPU (LOPU) and IVP technologies (Armstrong et al., 1992; Fry et al., 1998).

Recently, our research group conducted a series of studies to evaluate different hormonal protocols for collection of oocytes followed by IVP in Bos indicus (Nelore) and Bos taurus (Holstein) calves (Batista et al., 2016a). An experiment was conducted at a commercial beef farm near Paulínia city (São Paulo, Brazil). A total of 45 Nelore donors were used: 30 calves ( 3 to 4 month) and 15 cyclic heifers (18 to 24 month). In a second experiment conducted at the São Paulo University Campus (USP, Pirassununga Campus, SP, Brazil), a total of 34 Holstein donors were used, including 24 calves ( 3 to 4 month) and 10 cyclic heifers aged 14 to 16 month. All calves were randomly assigned to receive a superstimulatory treatment with pFSH (calves with pFSH, $n=15$ ) or not (calves without $\mathrm{FSH}, \mathrm{n}=15)$. Cycling heifers were subjected to a transvaginal ultrasound - guided OPU followed by IVP procedure at random stages of the estrous cycle.

All the calves underwent to LOPU. Calves without FSH were also subjected to LOPU at random stages of the estrous cycle. Superistimulated calves were treated before LOPU with an intravaginal progesterone device (day 0, Eazi-Breed CIDR, 0.33 g; Zoetis, São Paulo, SP, Brazil). After 5 days, calves received 4 treatments of porcine FSH (pFSH; $140 \mathrm{mg}$ of $\mathrm{pFSH}$; Folltropin, Agener, SP, Brazil) administered twice daily in decreasing doses (40 mg [day 5, AM], $40 \mathrm{mg}$ [day 5, $\mathrm{PM}$ ], $30 \mathrm{mg}$ [day 6, AM]) over a 2-day period. The LOPU was performed $12 \mathrm{~h}$ after the last treatment with pFSH (day 7).

In Bos indicus donors, the number of retrieved COCs was greater in calves with FSH and in cycling heifers, compared to calves without FSH $(\mathrm{P}=0.04)$. Furthermore, COC culture rate was greater in calves treated with FSH and in cycling heifers, compared to calves without FSH $(\mathrm{P}=0.01)$. However, cleavage rate was similar for all 3 groups (calves without FSH, calves with $\mathrm{FSH}$, and cycling heifers; $\mathrm{P}=0.41$; data shown in Table 1). Despite these positive effects of FSH treatment, the number of blastocysts produced was similar in calves with and without $\mathrm{FSH}$, and this number was lower than in cycling heifers $(\mathrm{P}<0.0001$; Table 1).

In Bos taurus donors, the number of visualized follicles $(\mathrm{P}=0.01)$ and recovered oocytes $(\mathrm{P}<0.0001)$ was greater in calves with FSH compared to calves without FSH and to cycling heifers. The number of cultured COCs was similar in calves without FSH and in cycling heifers, and both groups had fewer cultured COCs than did calves with FSH $(\mathrm{P}<0.0001)$. Despite these positive effects of FSH treatment, the number of blastocysts produced was similar in calves with and without FSH, and this number was lower than in cycling heifers (data summarized in Table 2).

The results presented herein demonstrate that it is possible to produce embryos for calves using LOPU/IVP. The FSH treatment could be used as a superstimulation treatment to improve the LOPU/IVP efficiency in young calves. However, further studies are needed to improve embryo production in calves compared to mature animals.

Table 1. Number of visualized follicles, COCs and blastocysts (mean \pm SEM) after LOPU-IVP in Bos indicus (Nelore) donor calves and after OPU - IVP in Bos indicus (Nelore) cycling heifers.

\begin{tabular}{|c|c|c|c|c|}
\hline \multirow[b]{2}{*}{ Item } & \multicolumn{4}{|c|}{ Bos indicus } \\
\hline & Calves without FSH & Calves with FSH & Cycling heifers & $P$ value $^{\mathrm{d}}$ \\
\hline Total follicles visualized & $19.7 \pm 4^{\mathrm{Z}}$ & $32.3 \pm 5.9^{\mathrm{y}}$ & $47.1 \pm 6.3^{\mathrm{x}}$ & 0.003 \\
\hline Total COCs retrieved & $13.5 \pm 3.6^{b}$ & $20.9 \pm 5.1^{\mathrm{ab}}$ & $29.9 \pm 5.3^{\mathrm{a}}$ & 0.04 \\
\hline Recovery rate $(\%)^{\mathrm{e}}$ & $68.5^{\mathrm{a}}$ & $64.7^{\mathrm{b}}$ & $63.6^{\mathrm{b}}$ & 0.02 \\
\hline COCs cultured & $4.7 \pm 1.4^{\mathrm{c}}$ & $11.3 \pm 4.0^{\mathrm{b}}$ & $18.1 \pm 4.0^{\mathrm{a}}$ & $<0.0001$ \\
\hline COCs cultured rate $(\%)^{\mathrm{f}}$ & $35.1^{b}$ & $54.3^{\mathrm{a}}$ & $60.6^{\mathrm{a}}$ & 0.01 \\
\hline Cleavage rate $(\%)^{\mathrm{g}}$ & 47.0 & 52.2 & 50.3 & 0.41 \\
\hline Blastocysts produced & $1.7 \pm 0.7^{\mathrm{b}}$ & $2.3 \pm 0.8^{\mathrm{b}}$ & $9.3 \pm 2.0^{\mathrm{a}}$ & $<0.0001$ \\
\hline Blastocyst rate $(\%)^{\mathrm{h}}$ & $12.9^{\mathrm{b}}$ & $11.3^{\mathrm{b}}$ & $30.9^{\mathrm{a}}$ & $<0.0001$ \\
\hline
\end{tabular}

${ }^{\mathrm{d}}$ Data with different superscripts in the same line differ with $\mathrm{P} \leq 0.05(\mathrm{a} \neq \mathrm{b} \neq \mathrm{c})$ or $\mathrm{P} \leq 0.06(\mathrm{x} \neq \mathrm{y} \neq \mathrm{z}) .{ }^{\mathrm{e}} \mathrm{Total}$ number of COCs/number of follicles aspirated. ${ }^{\mathrm{f}}$ Number of COCs cultured/number of follicles aspirated. ${ }^{\mathrm{g}} \mathrm{Number}$

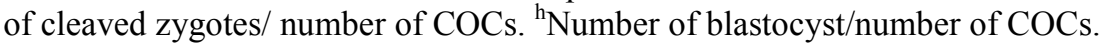


Table 2. Number of visualized follicles, COCs and blastocysts (mean \pm SEM) after LOPU-IVP in Bos taurus (Holstein) donor calves and after OPU - IVP in Bos taurus (Holstein) cycling heifers.

\begin{tabular}{lcccc}
\hline & \multicolumn{3}{c}{ Bos taurus } \\
\cline { 2 - 5 } & Calves without FSH & Calves with FSH & Cycling heifers & P-values \\
\hline Total follicles visualized & $22.7 \pm 4.2^{\mathrm{b}}$ & $54.3 \pm 9.5^{\mathrm{a}}$ & $24.9 \pm 3.6^{\mathrm{b}}$ & 0.01 \\
Total COCs retrieved & $11.7 \pm 2.4^{\mathrm{bx}}$ & $22.4 \pm 5.4^{\mathrm{a}}$ & $9.2 \pm 1.7^{\mathrm{cy}}$ & $<0.0001$ \\
Recovery rate $(\%)^{1}$ & $51.3^{\mathrm{a}}$ & $41.3^{\mathrm{a}}$ & $36.9^{\mathrm{b}}$ & 0.01 \\
COCs cultured & $3.6 \pm 1.0^{\mathrm{b}}$ & $12.3 \pm 3.5^{\mathrm{a}}$ & $4.7 \pm 1.3^{\mathrm{b}}$ & $<0.0001$ \\
COCs cultured rate $(\%)^{2}$ & $30.7^{\mathrm{b}}$ & $37.7^{\mathrm{a}}$ & $51.1^{\mathrm{a}}$ & 0.02 \\
Cleavage rate $(\%)^{3}$ & 17.8 & 30.5 & 26.1 & 0.47 \\
Blastocyst produced & $0.4 \pm 0.2$ & $0.7 \pm 0.4$ & $0.5 \pm 0.3$ & 0.78 \\
Blastocyst rate $(\%)^{4}$ & 2.9 & 2.0 & 4.3 & 0.60 \\
\hline
\end{tabular}

${ }^{\mathrm{d}}$ Data with different superscripts in the same line differ with $\mathrm{P} \leq 0.05(\mathrm{a} \neq \mathrm{b} \neq \mathrm{c})$ or $\mathrm{P} \leq 0.06(\mathrm{x} \neq \mathrm{y} \neq \mathrm{z})$. ${ }^{\mathrm{e}}$ Total number of $\mathrm{COCs} /$ number of follicles aspirated. ${ }^{\mathrm{f}}$ Number of $\mathrm{COC}$ s cultured/number of follicles aspirated. ${ }^{\mathrm{g}} \mathrm{Number}$ of cleaved zygotes/ number of COCs. ${ }^{\text {h}}$ Number of blastocyst/number of COCs.

Oocyte quality and IVP in prepubertal and pubertal heifers

Several research labs have successfully produced viable embryos from prepubertal heifers (Armstrong et al., 1992; Fry et al., 1998; Taneja et al., 2000). However, there are some concerns that oocytes from young females have a lower developmental capacity than those from adult donors (Khatir et al., 1996; Presicce et al., 1997; Majerus et al., 1999)

Recently, our research group performed a study at Santa Rita farm located near Descalvado city in São Paulo state (Guerreiro et al., 2014b), where a total of 120 donors of four animal categories were used, as follows: prepubertal heifers $(n=30)$, pubertal heifers $(\mathrm{n}=30)$, lactating cows $(\mathrm{n}=30)$ and nonlactating cows $(n=30)$. Donors were submitted to OPU without previous synchronization of the follicular wave. Six OPU sessions were performed with five animals of each category, 20 donors per session.

Immediately before the OPU, all follicles were quantified and all visible follicles $(\geq 2 \mathrm{~mm})$ were punctured and total recovered structures, quantity and quality of viable oocytes were registered. All viable oocytes were submitted to IVP and their development (cleavage and blastocyst rate) was evaluated. Sex-sorted sperm from the same bull and semen batch were used to fertilize oocytes from all donor categories in all OPU sessions. Produced embryos $(n=206)$ were transferred into crossbred recipients (Bos taurus x Bos indicus).

No difference was observed between experimental groups, regarding total number of aspirated follicles $(P=0.08)$. Despite similar number of total recovered oocytes $(\mathrm{P}=0.12)$, prepubertal heifers had an intermediate quantity of viable oocytes, and non-lactating cows produced more viable oocytes $(P=0.03)$, when compared to lactating cows. Still, prepubertal donors had lower cleavage rate $(\mathrm{P}<0.0001)$ and lower blastocyst rate $(\mathrm{P}<0.0001)$ compared to other categories (Table 3$)$.

Thus, it is concluded that prepubertal Holstein donors have low competence for in vitro embryo production, being non-lactating cows the most efficient category for IVP. Embryos originated from prepuberal animals resulted in inferior conception rate in comparison to embryos produced from lactating cows and nonlactating cows [prepubertal: $0.0 \%(0 / 15)^{\mathrm{b}}$; pubertal: $9.7 \%$ $(3 / 28)^{\mathrm{b}}$; lactating cows: $28.6 \%(10 / 25)^{\mathrm{a}}$; non lactating cows: $32.7 \%(36 / 74)^{\mathrm{a}}$; $\mathrm{P}<0.05$; Fig. 1]. However, similar conception rate was verified for embryos produced from pre-pubertal and pubertal donors.

Table 3. Number of aspirated follicles, oocytes and embryos produced after OPU-IVP in prepubertal and pubertal heifers, and in lactating and non-lactating cows from the Holstein breed. Data is presented as mean \pm standard error mean.

\begin{tabular}{|c|c|c|c|c|c|}
\hline \multirow[t]{2}{*}{ Item } & \multicolumn{2}{|c|}{ Heifer } & \multicolumn{2}{|c|}{ Cows } & \multirow[b]{2}{*}{$\mathrm{P}$ value } \\
\hline & Prepubertal & Pubertal & Lactating & Non-Lactating & \\
\hline $\mathrm{N}$ & 30 & 30 & 30 & 30 & \\
\hline Total follicles aspirated & $18.3 \pm 2.1$ & $17.3 \pm 1.2$ & $14.0 \pm 1.0$ & $17.7 \pm 1.7$ & 0.08 \\
\hline Total COC retrieved $^{1}$ & $14.2 \pm 2.2$ & $13.1 \pm 1.1$ & $9.8 \pm 1.1$ & $14.6 \pm 1.7$ & 0.12 \\
\hline COCs cultured & $10.5 \pm 1.8^{\mathrm{ab}}$ & $8.3 \pm 0.8^{\mathrm{ab}}$ & $6.5 \pm 0.9^{b}$ & $11.5 \pm 1.4^{\mathrm{a}}$ & 0.03 \\
\hline Cleavage rate $(\%)^{2}$ & $68.6^{\mathrm{b}}$ & $98.8^{\mathrm{a}}$ & $87.6^{\mathrm{a}}$ & $10.1^{\mathrm{a}}$ & $<0.0001$ \\
\hline Blastocysts produced & $0.5 \pm 0.2^{\mathrm{b}}$ & $1.1 \pm 0.2^{\mathrm{b}}$ & $1.2 \pm 0.4^{\mathrm{b}}$ & $4.2 \pm 0.6^{\mathrm{a}}$ & $<0.0001$ \\
\hline Blastocysts rate $(\%)^{3}$ & $4.8^{c}$ & $12.7^{\mathrm{b}}$ & $18.0^{\mathrm{b}}$ & $36.5^{\mathrm{a}}$ & $<0.0001$ \\
\hline
\end{tabular}

${ }^{1}$ COC - cumulus oocyte complex. ${ }^{2}$ Number of cleaved embryos/viable COCs. ${ }^{3}$ Number of blastocysts/viable COCs.

${ }^{a, b, c}$ Different letters within rows indicate statistical difference $(\mathrm{P}<0.05)$. 


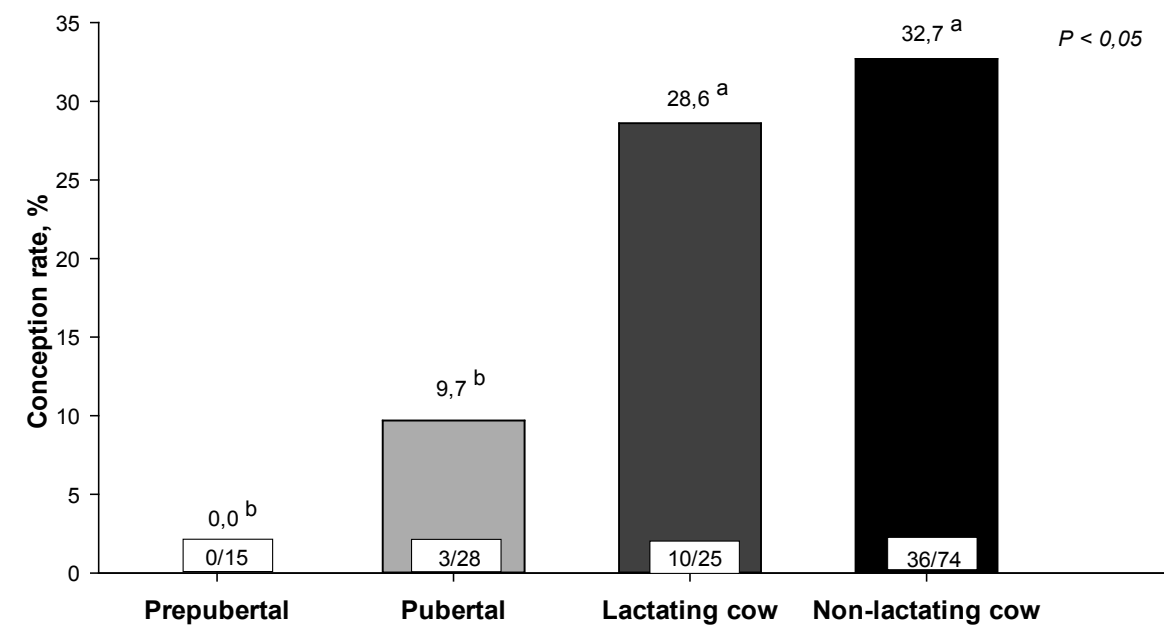

Figure 1. Conception rate after embryo transfer. Donors were prepubertal and pubertal heifers, and lactating and non-lactating cows from the Holstein breed.

We performed another trial with prepubertal Nelore heifer (Bos indicus) housed at Instituto de Zootecnia in Sertãozinho, São Paulo state (Batista et al., 2016; FMVZ/USP, São Paulo, Brazil; unpublished data). In this experiment we evaluated OPU-IVP production at different ages and cyclicity status. The experimental design included: prepubertal heifers aged 8 to 12 month $(\mathrm{n}=24)$, prepubertal heifers aged 18 to 22 month $(\mathrm{n}=20)$ and cycling heifers aged 22 to 26 month $(n=25)$. Data is summarized in Table 4.

Briefly, prepubertal heifers aged 8 to 12 month had lower numbers of visualized follicles, lower numbers of recovered oocytes than older heifers, despite cyclicity status. There were no differences across experimental groups in terms of the rate of COCs cultured or their cleavage rate. However, number of blastocysts produced, as well as blastocyst rate increased both with increasing age and after animals became cyclic (Table 4).

The results of OPU/IVP in prepubertal heifers demonstrate reduced efficiency compared to cycling heifers and adult animals. Further studies should be conducted to try to improve the efficiency of production in this age category.

Table 4. Number of visualized follicles, COCs and blastocysts (mean \pm SEM) after OPU - IVP in Bos indicus (Nelore) prepubertal and pubertal and heifers.

\begin{tabular}{|c|c|c|c|c|c|}
\hline \multirow[t]{2}{*}{ Item } & \multirow{2}{*}{$\begin{array}{l}\text { Prepubertal heifers } \\
(8-12 \text { month }) \\
(\mathrm{n}=24)\end{array}$} & \multirow{2}{*}{$\begin{array}{l}\text { Prepubertal heifers } \\
(18-22 \text { month }) \\
(\mathrm{n}=20)\end{array}$} & \multirow{2}{*}{$\begin{array}{c}\text { Pubertal heifers } \\
(22-26 \text { month }) \\
(n=25)\end{array}$} & \multicolumn{2}{|c|}{$\mathrm{P}_{\text {value }}{ }^{\mathrm{a}}$} \\
\hline & & & & $\operatorname{Age}^{b}$ & Ciclicality $^{\mathrm{c}}$ \\
\hline Total follicles visualized & $19.7 \pm 2.1$ & $41.3 \pm 5.28$ & $34.0 \pm 3.3$ & $<0.0001$ & 0.0002 \\
\hline Total COCs retrieved & $13.4 \pm 1.7$ & $30.8 \pm 5.8$ & $22.6 \pm 3.2$ & $<0.0001$ & $<0.0001$ \\
\hline Total COCs cleaved & $5.6 \pm 0.8$ & $14.8 \pm 2.5$ & $13.3 \pm 1.9$ & $<0.0001$ & $<0.0001$ \\
\hline COCs cultured & $7.6 \pm 1.0$ & $16.8 \pm 2.7$ & $15.1 \pm 2.2$ & $<0.0001$ & $<0.0001$ \\
\hline COCs cultured rate $(\%)^{\mathrm{d}}$ & 57.0 & 54.0 & 60.0 & 0.13 & 0.45 \\
\hline Cleavage rate $(\%)^{\mathrm{e}}$ & 73.0 & 88.0 & 84.0 & $<0.0001$ & 0.25 \\
\hline Blastocysts produced & $1.5 \pm 0.3$ & $4.7 \pm 0.9$ & $7.2 \pm 1.2$ & $<0.0001$ & $<0.0001$ \\
\hline Blastocyst rate $(\%)^{\mathrm{f}}$ & 20.2 & 28.1 & 47.0 & 0.05 & $<0.0001$ \\
\hline
\end{tabular}

${ }^{a}$ Effect of evaluated group. ${ }^{b}$ Effect of age in the prepubertal group (8-12 month $v s .18-24$ month). ${ }^{c}$ Effect of cyclicity (cyclic vs. non cyclic). ${ }^{\mathrm{d}}$ Number of viable oocytes/number of total oocytes. ${ }^{\mathrm{e}}$ Number of cleaved oocytes/number of cultured oocytes. ${ }^{\mathrm{f}}$ Number of blastocysts/number of cultured oocytes.

\section{Oocyte quality and IVP in pregnant donors}

Recently, our research group studied the effect of pregnancy on oocyte quality and IVP of Holstein heifers (Bayeux et al., 2016). We evaluated 179 Holstein donors (Bos taurus) of 3 categories: prepubertal heifers ( 8 to 10 month; $\mathrm{n}=60$ ); pubertal heifers (10 to 12 month; $\mathrm{n}=60)$ and pregnant heifers (14 to 18 month; $n=59)$. All animals underwent ovum pickup (OPU) at random stages of the estrous cycle. Sex-sorted sperm from the same bull and semen batch were used to fertilize oocytes from all donor categories in all OPU sessions. Pubertal heifers had a greater number of recovered oocytes as well as COCs cultured compared to other categories. In contrast, cleavage rate was similar between pubertal and pregnant heifers. Interestingly, pregnant heifers had a greater number of embryos produced per OPU and ultimately greater blastocyst rate when compared to other heifer-categories (Table 5). These results indicate that pregnant heifers were more efficient in terms of IVP compared to prepubertal and pubertal Holstein (Bos taurus) heifers. 
Table 5. Number of recovered oocytes, COCs cultured, blastocysts, cleavage and blastocyst rate after OPU - IVP in Bos taurus (Holstein) donors in different categories.

\begin{tabular}{lcccc}
\hline \multirow{1}{*}{\multicolumn{1}{c}{ Item }} & \multicolumn{4}{c}{ Heifers } \\
\cline { 2 - 5 } & $\begin{array}{c}\text { Prepubertal } \\
(\mathrm{n}=60)\end{array}$ & $\begin{array}{c}\text { Pubertal } \\
(\mathrm{n}=60)\end{array}$ & $\begin{array}{c}\text { Pregnant } \\
(\mathrm{n}=59)\end{array}$ & P value \\
\hline Number of COCs retrieved & $9.8 \pm 1.3^{\mathrm{b}}$ & $15.6 \pm 1.4^{\mathrm{a}}$ & $9.8 \pm 1.6^{\mathrm{b}}$ & 0.001 \\
COCs cultured & $4.6 \pm 0.6^{\mathrm{b}}$ & $9.1 \pm 0.9^{\mathrm{a}}$ & $5.6 \pm 1.1^{\mathrm{b}}$ & 0.001 \\
Cleavage rate $(\%)^{\mathrm{d}}$ & $31^{\mathrm{b}}$ & $56^{\mathrm{a}}$ & $78^{\mathrm{a}}$ & 0.001 \\
Blastocysts produced & $0.13 \pm 0.1^{\mathrm{c}}$ & $0.9 \pm 0.2^{\mathrm{b}}$ & $1.8 \pm 0.3^{\mathrm{a}}$ & $<0.001$ \\
Blastocyst rate $(\%)^{\mathrm{e}}$ & $2^{\mathrm{c}}$ & $14^{\mathrm{b}}$ & $37^{\mathrm{a}}$ & $<0.001$ \\
\hline
\end{tabular}

${ }^{\mathrm{d}}$ Number of cleaved oocytes/number of cultured oocytes. ${ }^{\mathrm{e}}$ Number of blastocysts/number of cultured oocytes. Abbreviations: COC, cumulus - oocyte complex; IVP, in vitro embryo production; OPU, ovum pickup. Data with different superscripts in the same row differ at $\mathrm{P}<0.001$.

Oocyte quality and IVP during the early postpartum in donors

To assess the impact of early postpartum period on IVP in beef and dairy cattle, we have recently performed a study utilizing Bos indicus (Nelore; Pierucci et al., 2015) and Bos taurus (Holstein; Sala, 2013) cows. Ultrasound-guided follicular aspirations were performed every 14 days, from 30 to 86 days postpartum. Then, within breed, cows were blocked when $50 \%$ of the animals were cycling, which occurred at 30 days postpartum for Bos taurus and at 44 days postpartum in Bos indicus cows.
Thus, we ended up with 2 experiments: experiment 1, Bos taurus cows with $\mathrm{CL}$ present $(\mathrm{n}=14)$ and without $\mathrm{CL}$ present $(\mathrm{n}=11)$ at 30 days with postpartum, and experiment 2, Bos indicus cows without CL present $(\mathrm{n}=$ $7)$ and without CL present $(n=8)$ at 44 days postpartum.

There was a significant effect of postpartum period, only for Nelore cows, in the number of aspirated follicles, recovered oocytes, and number of viable oocytes. In contrast, number of blastocysts (Fig. 2) as well as blastocyst rate did not differ with increasing days postpartum and cyclicity, both in Bos indicus and Bos taurus cows (Fig. 3).

A

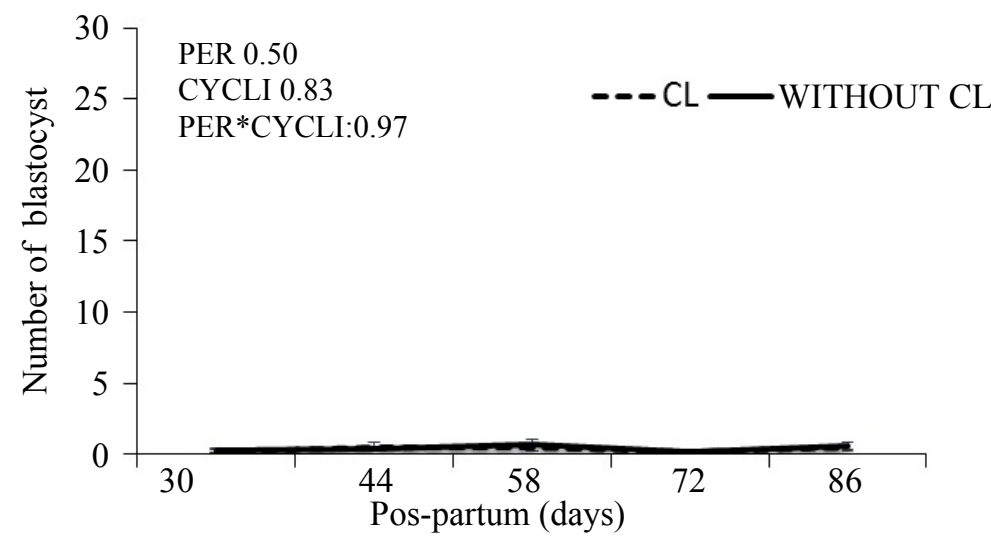

B

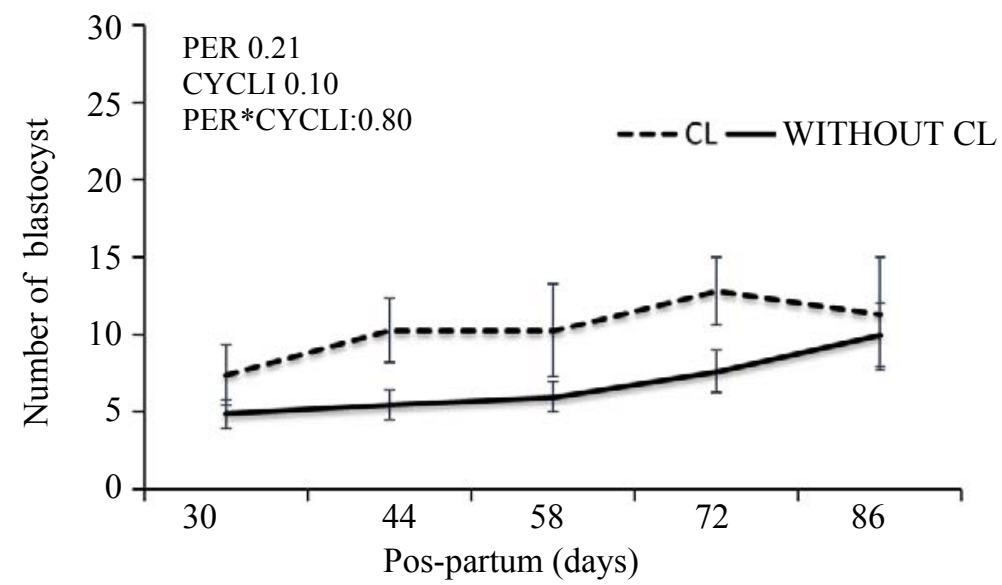

Figure 2. Number of blastocysts according to days postpartum in Holstein Bos taurus (A) and Nelore Bos indicus cows (B). 
As observed in a previous study (Matoba et al., 2012), these results do not provide evidence of an effect of lactation-induced metabolic stress on oocyte developmental competence, in the early postpartum in dairy and beef cows, in terms of morphological ability to develop following in vitro fertilization (IVF). Previous research has shown impairment in fertility during early post partum due to metabolic disorder, mainly related to negative energy balance (Leroy et al., 2012). In these studies, fertility was evaluated after artificial insemination, with significant endocrine and metabolic alterations in the microenvironments of the dominant follicle. In studies with OPU/IVP, follicles are aspirated with approximately 2 to $3 \mathrm{~mm}$, before the growth phase of the dominant follicle. This may partly explain the difference in results between experiments.
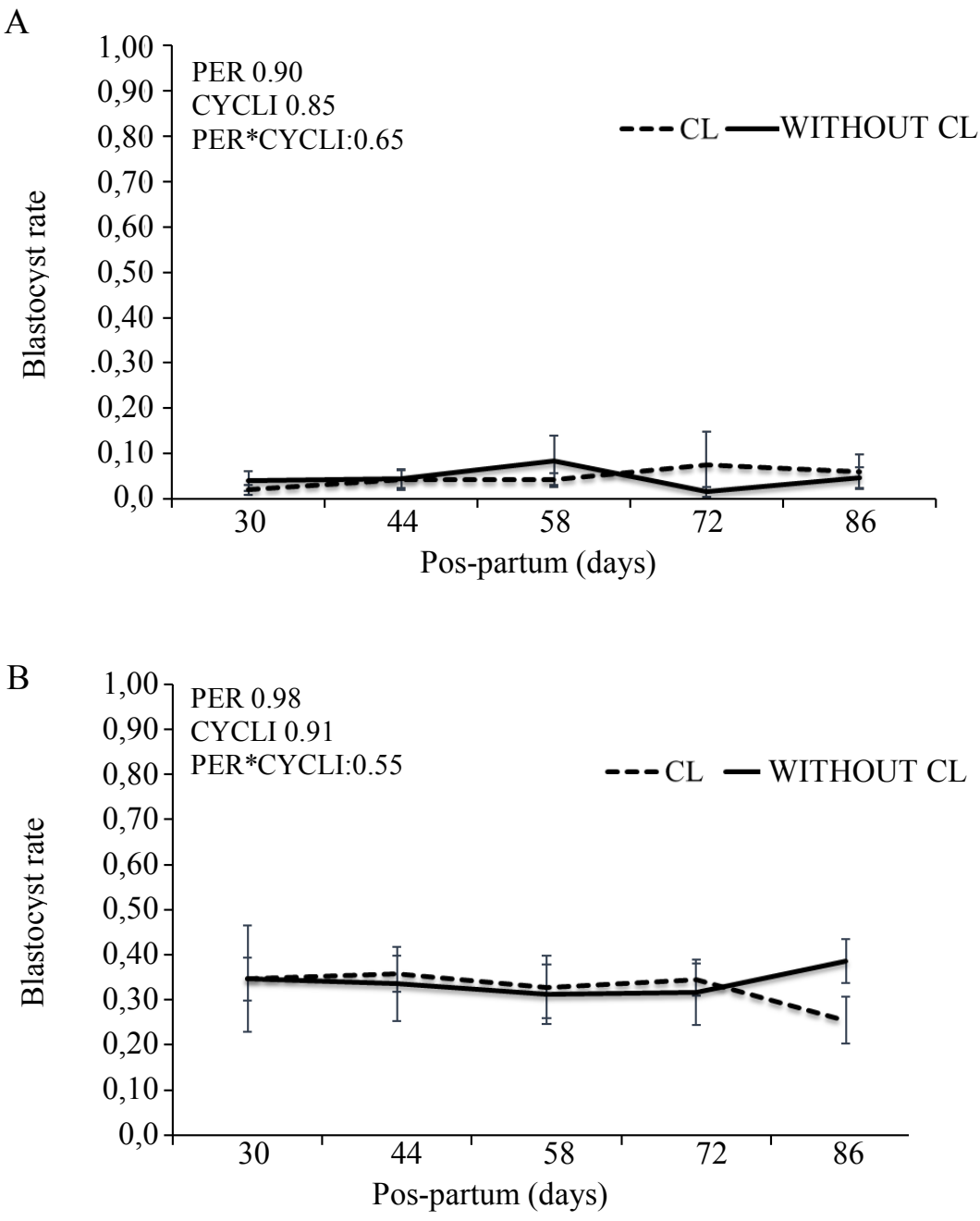

Figure 3. Blastocyst rate according to days postpartum in Holstein Bos taurus (A) and Nelore Bos indicus cows (B).

Oocyte quality and IVP during the during early or late lactation period

Clearly evaluating the effects of lactation on oocyte quality can be rather complex. For example, testing the isolated effects of lactation status per se on oocyte quality might be confounded by interactions with heat-stress for example, since lactating cows are generally more susceptible to heat stress. Also, lactating cows may suffer from different metabolic problems as lactation progresses until the dry-period. In addition, the type of diet and level of dry matter intake between lactating and non-lactating cows may also influence results of OPU-IVP. Despite of that, the negative effects of excessive energy intake was shown to compromise in vitro oocyte developmental competence, especially in over-conditioned (high body condition score) females (Adamiak, 2005). The mechanisms mediating these negative effects on oocyte competence may be related to endocrine alterations, such as hyperinsulinemia, peripheral insulin resistance, and increased glucose, NEFA and IGF-I, which may interfere with glucose transport in embryo cells and induce increased rates of apoptosis.

Lactating cows have been selected for milk production, making the modern dairy cow prone to peripheral insulin resistance to maintain milk production. Several factors have been involved to induce insulin resistance in lactating cows including excessive negative energy balance in early postpartum. Intriguingly, lactating dairy cows are again prone to insulin resistance that appears to happen more evidently in animals with greater body condition scores and having an excessive intake of diets with a high energy content. This is a rather common issue particularly in commercial dairies utilizing a single diet throughout the entire lactation. To 
test whether stage of lactation and possible interactions with insulin resistance might influence oocyte quality, our research group (Baruselli et al. 2016), utilized Holstein cows that were either at early or late days in milk production at the moment of OPU-IVP. Results of this study clearly showed that insulin resistance associated with late lactation period (later lactation cows had greater circulating insulin levels) can disrupt oocyte quality and lower the efficiency of IVP. For example, we observed that cows at later lactation had a greater number of recovered oocytes per OPU session. In contrast, number of blastocysts, as well as blastocyst rates, were greatly reduced in cows at later lactation. In addition, a number of apoptotic genes were upregulated in cows with greater days in milk. These findings corroborate previous studies showing that lactating cows at later lactation are prone to insulin resistance, which clearly seem to lower oocyte viability during IVP procedures.

Table 6. Ovum pick-up and in vitro embryo production results from high producing Holstein cows during early or late lactation periods.

\begin{tabular}{|c|c|c|c|}
\hline \multirow{2}{*}{ Item } & \multicolumn{2}{|c|}{ Stage of lactation } & \multirow[b]{2}{*}{$P$ value } \\
\hline & Early & Late & \\
\hline No. of animals & 70 & 67 & \\
\hline DIM, days & $110.5 \pm 20.8$ & $425.6 \pm 21.0$ & N/A \\
\hline Milk production, $\mathrm{kg} /$ day & $34.3 \pm 1.2$ & $23.4 \pm 1.2$ & $<0.0001$ \\
\hline No. of insemination & $0.7 \pm 0.2$ & $7.0 \pm 0.2$ & $<0.0001$ \\
\hline No. of lactation & $2.4 \pm 0.1$ & $1.9 \pm 0.2$ & 0.05 \\
\hline BCS (1-5 scale) & $2.79 \pm 0.06$ & $3.15 \pm 0.07$ & $<0.0001$ \\
\hline No. of follicles & $14.8 \pm 2.4$ & $22.7 \pm 2.4$ & 0.0016 \\
\hline Recovery rate, $\%$ & $46.4 \pm 4.4$ & $53.8 \pm 4.5$ & 0.10 \\
\hline No. of oocytes & $7.3 \pm 2.0$ & $14.3 \pm 2.0$ & 0.0004 \\
\hline No. of viable oocytes & $4.6 \pm 1.6$ & $9.7 \pm 1.6$ & 0.0010 \\
\hline No. of cleaved oocytes (day 3 ) & $4.7 \pm 0.6$ & $3.9 \pm 0.6$ & 0.10 \\
\hline Cleavage rate, $(\%)$ & $48.0 \pm 0.1$ & $41.4 \pm 0.1$ & 0.08 \\
\hline No. of blastocyst (day 7) & $2.2 \pm 0.4$ & $1.4 \pm 0.3$ & 0.06 \\
\hline Blastocyst rate $(\%)$ & $23.0 \pm 0.1$ & $13.3 \pm 0.1$ & 0.0005 \\
\hline
\end{tabular}

Adapted from Baruselli et al., 2016.

\section{Oocyte quality and IVP in non-lactating donors}

Oocyte quality has been considered an important factor contributing to the low fertility reported for high producing lactating dairy cattle (Walsh et al., 2011). Thus, we hypothesized that OPU-IVP procedures would result in a higher number of blastocysts per OPU session in non-lactating than in lactating donors. Our data showed higher number of blastocysts per OPU session in non-lactating than in lactating donors (Vieira et al., 2014). Non-lactating cows produced a higher blastocyst rate (41.9 vs. $13.4 \%$; $\mathrm{P}=0.001)$ and a higher number of transferable embryos per OPU $(3.5 \pm 0.5$ vs. $1.3 \pm 0.3 ; \mathrm{P}=0.003)$ than lactating Holsteins cows. Similar results were observed in a previously mentioned trial performed by our group (Table 3).

Dairy cows have a peculiar metabolic system, linked to nutrition and disruption of endocrine profiles. The metabolic profile of lactating dairy cows is commonly characterized by lower concentrations of progesterone and estradiol (Wiltbank et al., 2006) and increased concentrations of NEFA (nonesterified fatty acids) and BHBA (b-hydroxybutyrate; Leroy et al., 2005); and this peculiar metabolism has been associated with a suboptimal follicle microenvironment, compromising oocyte quality and resulting in a failure to conceive (Sartori et al., 2002, 2004; Wiltbank et al., 2006; Leroy et al., 2008a, b; Walsh et al., 2011). Therefore, the greater challenge of lactating cows to maintain an optimal reproductive efficiency may help explain the lower results observed in IVP. Thus, non- lactating donors may be considered the preferred donor in OPU-IVP programs, due to the higher yield of embryos per OPU session.

In another experiment (Sales et al., 2015) we studied the effects of different dietary energy levels [100 and $170 \%$ for maintenance (M) and high energy $(1.7 \mathrm{M})$, respectively] on metabolic, endocrine, and reproductive parameters in non-lactating Bos indicus (Gir; $\mathrm{n}=14$ ) and Bos taurus (Holstein; $\mathrm{n}=14$ ) cows submitted to OPU and IVP each 14 days. We measured glucose and insulin concentrations and performed glucose tolerance tests and the relative quantification of transcripts (PRDX1, HSP70.1, GLUT1, GLUT5, IGF1R, and IGF2R) from oocytes recovered at the end of the experimental period. No interactions were observed between the effects of breed and dietary energy level on the qualitative (viable oocytes, quality grade, and oocyte quality index) and quantitative (oocytes recovered) variables. There were no effects of dietary energy level on the qualitative and quantitative oocyte variables. In vitro embryo production (cleavage and blastocyst rates and number of embryos) was similar between diets, but the $1.7 \mathrm{M}$ diet reduced in vitro embryo production in Bos indicus cows after 60 days of treatment. Moreover, Bos indicus cows on the $1.7 \mathrm{M}$ diet showed lower transcript abundance for the HSP70.1, GLUT1, IGF1R, and IGF2R genes. All cows fed 1.7M diets had greater glucose and insulin concentrations and greater insulin resistance according to the glucose tolerance test. These results suggest that intake of a high energy diet for a long period reduces in vitro embryo production in non-lactating Bos indicus cows by causing 
a hyperinsulinemic state, and promoting downregulation of genes involved in cellular metabolism.

\section{Conclusions and future directions}

In conclusion, the IVP from younger beef or dairy cattle seem quite possible, although improvements are still needed to further improve this technology that came as a complement for genomic testing. More importantly, veterinarians working with OPU-IVP need to account for varying physiological aspects when working with specific cattle breeds (Bos indicus vs. Bos taurus). For example, avoiding working with cows submitted to a high energy diet for a long period and/or under heat stress, both factors that may induce poor oocyte quality, is highly advisable.

\section{References}

Adamiak SJ. 2005. Impact of nutrition on oocyte quality: cumulative effects of body composition and diet leading to hyperinsulinemia in cattle. Biol Reprod, 73:918-926.

Armstrong DT, Holm P, Irvine B, Petersen BA, Stubbings RB, McLean D, Stevens G, Seamark RF. 1992. Pregnancies and live birth from in vitro fertilization of calf oocytes collected by laparoscopic follicular aspiration Theriogenology, 38:667-678.

Baruselli PS, Vieira LM, Sá Filho MF, Mingoti RD, Ferreira RM, Chiaratti MR, Oliveira LH, Sales JN, Sartori R. 2016. Associations of insulin resistance later in lactation on fertility of dairy cows. Theriogenology, 86:263-269.

Batista EOS, Macedo GG, Sala RV, Ortolan M, Sá Filho MF, Del Valle TA, Jesus EF, Lopes R, Rennó FP, Baruselli PS. 2014. Plasma Antimullerian Hormone as a Predictor of Ovarian Antral Follicular Population in Bos indicus (Nelore) and Bos taurus (Holstein) Heifers. Reproduction in Domestic Animals, 49:448-452.

Batista EO, Guerreiro BM, Freitas BG, Silva JC, Vieira LM, Ferreira RM, Rezende RG, Basso AC, Lopes RN, Rennó FP, Souza AH, Baruselli PS. 2016a. Plasma anti-Müllerian hormone as a predictive endocrine marker to select Bos taurus (Holstein) and Bos indicus (Nelore) calves for in vitro embryo production. Domest Anim Endocrinol, 54:1-9.

Batista EO, Vieira LM, Sá Filho MF, Dias EA, Bayeux BM, Accorsi MF, Monteiro FM, Souza AH, Baruselli PS, D'Occhio MJ. 2016b. Ovarian follicular growth suppression by long-term treatment with a GnRH agonist and impact on small follicle number, oocyte yield, and in vitro embryo production in Zebu beef cows. Theriogenology, 85:1680-1687.

Bayeux BM, Carvalho LM, Mingoti RD, Watanabe YF, Oliveira AS, Chiba MO, Azrak AJ, Castro PMN, Souza AH, PS Baruselli. 2016. Effect of animal category (prepubertal, pubertal and pregnant) on in vitro embryo production in Holstein heifers. Anim Reprod, 13. (abstract).

Betteridge KJ, Smith C, Stubbings RB, Xu KP, King WA. 1989. Potential genetic improvement of cattle by fertilization of fetal oocytes in vitro. $J$ Reprod Fertil Suppl, 38:87-98.

Desjardins C, Hafs HD. 1969. Maturation of bovine female genitalia from birth through puberty. J Anim Sci, 25:502-507.

Ericksson BH. 1966. Developmental and senescence of the postnatal bovine ovary. J Anim Sci, 25:800-805.

Ferreira RM, Ayres H, Chiaratti MR, Ferraz ML, Araújo AB, Rodrigues CA, Watanabe YF, Vireque AA, Joaquim DC, Smith LC, Meirelles FV, Baruselli PS. 2011. The low fertility of repeat-breeder cows during summer heat stress is related to a low oocyte competence to develop into blastocysts. J Dairy Sci, 94:2383-2392.

Ferreira RM, Chiaratti MR, Macabelli CH, Rodrigues CA, Ferraz ML, Watanabe YF, Smith LC, Meirelles FV, Baruselli PS. 2016. The infertility of repeat-breeder cows during summer is associated with decreased mitochondrial DNA and increased expression of mitochondrial and apoptotic genes in oocytes. Biol Reprod, 94:66, 1-10.

Fry RC, Simpson TL,Squires TJ. 1998. Ultrasonically guided transvaginal oocyte recovery from calves treated with or without GnRH. Theriogenology, 49:1077-1082.

Gimenes LU, Ferraz ML, Fantinato-Neto P, Chiaratti MR, Mesquita LG, Sá Filho MF, Meirelles FV, Trinca LA, Rennó FP, Watanabe YF, Baruselli PS. 2015. The interval between the emergence of pharmacologically synchronized ovarian follicular waves and ovum pickup does not significantly affect in vitro embryo production in Bos indicus, Bos taurus, and Bubalus bubalis. Theriogenology 83:385-393.

Guerreiro BM, Batista EO, Vieira LM, Sá Filho MF, Rodrigues CA, Castro Netto A, Silveira CR, Bayeux BM, Dias EA, Monteiro FM, Accorsi M,Lopes RN, Baruselli PS. 2014a. Plasma anti-mullerian hormone: an endocrine marker for in vitro embryo production from Bos taurus and Bos indicus donors. Domest Anim Endocrinol, 49:96-104.

Guerreiro BM, Rodrigues CA, Castro Neto A, Silveira CRA, Vieira LM, Oliveira RC, Freitas BG, Baruselli PS. 2014b. Prepubertal Holstein heifers have low efficiency when submitted to ovum pick-up and in vitro embryo production. Anim Reprod, 11:405. (abstract).

Khatir H, Lonergan P, Carolan C, Mermillod P. 1996. Prepubertal bovine oocyte: a negative model for studying oocyte developmental competence. Mol Reprod Dev, 45:231-239.

Leroy JL, Vanholder T, Mateusen B, Christophe A, Opsomer G, de Kruif A, Genicot G, Van Soom A. 2005. Non-esterified fatty acids in follicular fluid of dairy cows and their effect on developmental capacity of bovine oocytes in vitro. Reproduction, 130:485-495.

Leroy JL, Van Soom A, Opsomer G, Goovaerts IG, Bols PE. 2008a. Reduced fertility in high-yielding dairy cows: are the oocyte and embryo in danger? Part II. Mechanisms linking nutrition and reduced oocyte and embryo quality in high-yielding dairy cows. Reprod Domest Anim, 43:623-632.

Leroy JL, Vanholder T, Van Knegsel AT, GarciaIspierto I, Bols PE. 2008b. Nutrient prioritization in dairy cows early postpartum: mismatch between 
metabolism and fertility? Reprod Domest Anim, 43(suppl. 2):96-103.

Leroy JL, Rizos D, Sturmey R, Bossaert P, Gutierrez-Adan A, Van Hoeck V, Valckx S, Bols PE.

2012. Intrafollicular conditions as a major link between maternal metabolism and oocyte quality: a focus on dairy cow fertility. Reprod Fertil Dev, 24:1-12.

Lonergan P, Monaghan P, Rizos D, Boland MP, Gordon I. 1994. Effect of follicle size on oocyte quality and developmental competence following maturation, fertilization, and culture in vitro. Mol Reprod Dev, 37:48-53.

Lonergan P. 2011. Influence of progesterone on oocyte quality and embryo development in cows. Theriogenology, 76:1594-1601.

Maclellan LJ, Whyte TR, Murray A, Fitzpatrick LA, Earl CR, Aspden WJ, Kinder JE, Grotjan HE, Walsh J, Trigg TE, D'Occhio MJ. 1998. Superstimulation of ovarian follicular growth with FSH oocyte recovery, and embryo production from Zebu (Bos indicus) calves: effects of treatment with a GnRH agonist or antagonist. Theriogenology, 49:1317-1329.

Majerus V, De Roover R, Etienne D, Kaidi S, Massip A, Dessy F, Donnay I. 1999. Embryo production by ovum pick up in unstimulated calves before and after puberty. Theriogenology, 52:1169-1179.

Matoba S, O'Hara L, Carter F, Kelly AK, Fair T, Rizos D, Lonergan P. 2012. The association between metabolic parameters and oocyte quality early and late postpartum in Holstein dairy cows. $J$ Dairy Sci, 95:1257-1266.

Merton JS, de Roos AP, Mullaart E, de Ruigh L, Kaal L, Vos PL, Dieleman SJ. 2003. Factors affecting oocyte quality and quantity in commercial application of embryo technologies in the cattle breeding industry. Theriogenology, 59:651-674.

Pierucci JC, Silveira CRA, Santos GL, Yamazaki W, Yamazaki LTS, Dias EAR, Paz CC, F. Monteiro M, Baruselli PS, Gimenes LU. 2015. Evaluation of in vitro embryo production according to the cyclicity of Nellore (Bos indicus) cows submitted to opu in different postpartum moments. Anim Reprod, 12:676. (abstract).

Pontes JH, Silva KC, Basso AC, Rigo AG, Ferreira CR, Santos GM, Sanches BV, Porcionato JP, Vieira PH, Faifer FS, Sterza FA, Schenk JL, Seneda MM. 2010. Large-scale in vitro embryo production and pregnancy rates from Bos taurus, Bos indicus, and indicus-taurus dairy cows using sexed sperm. Theriogenology, 74:1349-1355.

Presicce GA, Jiang S, Simkin M, Zhang L, Looney CR, Godke RA, Yang X. 1997. Age and hormonal dependence of acquisition of oocyte competence for embryogenesis in prepubertal calves. Biol Reprod, 56:386-392.
Sala RV. 2013. Influência das concentrações de AGNE na qualidade oócitaria e produção in vitro de embriões de vacas Holandesas no início da lactação. São Paulo, SP: Universidade de São Paulo, Faculdade de Medicina Veterinária e Zootecnia. Dissertação.

Sales JN, Iguma LT, Batista RI, Quintão CC, Gama MA, Freitas C, Pereira MM, Camargo LS, Viana JH, Souza JC, Baruselli PS. 2015. Effects of a highenergy diet on oocyte quality and in vitro embryo production in Bos indicus and Bos taurus cows. J Dairy Sci, 98:3086-3099.

Sartori R, Rosa GJ, Wiltbank MC. 2002. Ovarian structures and circulating steroids in heifers and lactating cows in summer and lactating and dry cows in winter. J Dairy Sci, 85:2813-2822.

Sartori R, Haughian JM, Shaver RD, Rosa GJ, Wiltbank MC. 2004. Comparison of ovarian function and circulating steroids in estrous cycles of Holstein heifers and lactating cows. J Dairy Sci, 87:905-920.

Sartori R, Gimenes LU, Monteiro PL Jr, Melo LF, Baruselli PS, Bastos MR. 2016. Metabolic and endocrine differences between Bos taurus and Bos indicus females that impact the interaction of nutrition with reproduction. Theriogenology, 86:32-40.

Seneda MM, Esper CR, Garcia JM, Oliveira JA, Vantini R. 2001. Relationship between follicle size and ultrasoound-guided transvaginal oocyte recovery. Anim Reprod Sci, 67:37-43.

Taneja M, Bols PE, Van de Velde A, Ju JC, Schreiber D, Tripp MW, Levine H, Echelard Y, Riesen J, Yang X. 2000. Developmental competence of juvenile calf oocytes in vitro and in vivo: influence of donor animal variation and repeated gonadotropin stimulation. Biol Reprod, 62:206-213.

Torres-Júnior JR, Pires MFA, de Sá WF, Ferreira AM, Viana JH, Camargo LS, Ramos AA, Folhadella IM, Polisseni J, C Freitas,Clemente CA, de Sá Filho MF, Paula-Lopes FF, Baruselli PS. 2008. Effect of maternal heat-stress on follicular growth and oocyte competence in Bos indicus cattle. Theriogenology, 69:155-166.

Vieira LM, Rodrigues CA, Castro Netto A, Guerreiro BM, Silveira CR, Moreira RJ, Sá Filho MF, Bó GA, Mapletoft RJ, Baruselli PS. 2014. Superstimulation prior to the ovum pick-up to improve in vitro embryo production in lactating and nonlactating Holstein cows. Theriogenology, 82:318-324.

Walsh SW, Williams EJ, Evans AC. 2011. A review of the causes of poor fertility in high milk producing dairy cows. Anim Reprod Sci, 123:127-138.

Wiltbank M, Lopez H, Sartori R, Sangsritavong S, Gümen A. 2006. Changes in reproductive physiology of lactating dairy cows due to elevated steroid metabolism. Theriogenology, 65:17-29. 